\title{
Maladaptation of trout spermatozoa to fresh water is related to oxidative stress and proteome changes
}

\author{
J Nynca, M Słowińska, S Judycka and A Ciereszko \\ Department of Gametes and Embryo Biology, Institute of Animal Reproduction and Food Research, Polish Academy \\ of Sciences, Olsztyn, Poland \\ Correspondence should be addressed to J Nynca; Email: j.nynca@pan.olsztyn.pl
}

\begin{abstract}
Rainbow trout sperm are 'maladapted' to freshwater spawning, resulting in shorter duration of sperm motility in fresh water compared to buffered saline solution. We hypothesized that different sperm motility-activating media have various effects on sperm motility characteristics and oxidative stress, as well as on the protein profiles of rainbow trout sperm. We designed an experimental model for activation of rainbow trout sperm motility in different osmotic conditions: (i) isosmotic and (ii) hypoosmotic. Spermatozoa activation with hypoosmotic solution was associated with lower values for sperm motility parameters (52\%) and an induced increase in ROS level (19.4\%) in comparison to isosmotic activation with isosmotic solution (67 and 9.5\% for sperm motility and ROS, respectively). Hypoosmotic activation resulted in a higher number of differentially abundant sperm proteins (out of which $\mathbf{5 0}$ were identified) compared to isosmotic conditions, where only two spots of protein disulfide-isomerase 6 were changed in abundance. The proteins are mainly involved in the TCA cycle, tight and gap junction signaling, Sertoli cell-Sertoli cell junction signaling and asparagine degradation. Our results, for the first time, indicate that during hypoosmotic activation of sperm motility, osmotic stress triggers oxidative stress and disturbances mostly to structural proteins and metabolic enzymes. Our results strongly suggest that comparative physiological and biochemical analysis of rainbow trout sperm characteristics in isosmotic and hypoosmotic conditions could be a useful model for studying the mechanism of sperm activation in salmonid fish.

Reproduction (2019) 157 485-499
\end{abstract}

\section{Introduction}

In teleost fish, spermatozoa remain quiescent in the testes and efferent ducts, and activation of motility is induced by changes in the ionic and osmotic aquatic environment into which the sperm are ejaculated (Morisawa \& Suzuki 1980). Sperm of teleost fish in general have a short period of motility ( $30 \mathrm{~s}$ to $5 \mathrm{~min}$ ) and commonly the swimming duration of sperm from marine fish is longer than that of sperm from freshwater fish (Billard \& Cosson 1992). Since fish spermatozoa are motile for a very short time, the initiation and activation of sperm motility must be precisely controlled in order to prevent energy exhaustion prior to ejaculation. Sperm motility is acquired under the control of many external and internal factors and is based on the specialized structure of the sperm flagellum. Fish spermatozoa show species differences in the initiation, duration and pattern of motility (Billard \& Cosson 1992). In salmonids, the reduction of the external $\mathrm{K}^{+}$ concentration, upon dilution of semen in water, initiates sperm motility, while in freshwater cyprinids, flagellar motility is initiated by hypoosmotic shock (Morisawa \& Suzuki 1980, Stoss 1983, Morisawa 1985). A decrease in environmental $\mathrm{K}^{+}$concentration causes $\mathrm{K}^{+}$efflux through specific membrane channels, leading to membrane hyperpolarization which in turn determines the $\mathrm{Ca}^{2+}$ influx by calcium channels. An extremely rapid transition of spermatozoa from an immotile to motile state occurs, which is a necessary condition for external fertilization in the running water of streams.

The maladaptation of fish, including trout, spermatozoa to fresh water was recognized a long time ago by Huxley (1930) who indicated that the physiology of trout spermatozoa is imperfectly adapted to fresh water. This suggestion is supported by numerous papers indicating better and longer swimming of spermatozoa in buffered saline solution (Alavi \& Cosson 2006) compared to fresh water. Poor resistance of spermatozoa to hypoosmotic shock (Billard \& Cosson 1990) is considered to be the one of the limiting factors for the duration of spermatozoan motility in freshwater fish. Since a very short window of sperm motility (Kime et al. 2001) is found in salmonids (less than 30s), buffered saline solution was developed to secure good activation of spermatozoa without exposing them to extreme osmotic conditions, resulting in prolonged sperm motility and thus a higher chance of successful fertilization (Billard 1978). The mechanism related to activation of sperm motility in isosmotic and hypoosmotic conditions is not fully understood; 
most studies concern morphological changes of sperm and focus on examining alterations of the structural components of sperm flagella and sperm energetics (Dzyuba \& Cosson 2014, Dzyuba et al. 2017).

The motility criteria used to characterize fish sperm movement and sperm flagella are well described; however, changes in the protein profiles of sperm as a consequence of motility triggering have been examined only for a few fish species. A proteomic approach was introduced to study the activation of sperm motility in saltwater fish such as gilthead and stripped sea bream (Zilli et al. 2008) and freshwater common carp and sterlet (Dietrich et al. 2016, Gazo et al. 2017). The study of Dietrich et al. (2016) revealed that activation of carp sperm motility is associated with profound changes to the sperm proteome; 72 differentially expressed proteins were identified, mainly involved in ubiquitinproteasome pathways, glycolysis, the tricarboxylic acid (TCA) cycle and remodeling and are putatively related to sperm energy metabolism and motility. However, those authors examined the changes in carp sperm proteome during activation only in hypoosmotic conditions in hatchery water. Since it clearly emerges that there are different species-specific mechanisms of sperm motility initiation between cyprinid and salmonid fish, it is unknown at present whether quantitative and/or qualitative protein changes occur during the rainbow trout sperm motility period. To examine this issue, in this study, we designed an experimental model for sperm motility activation of rainbow trout in two different osmotic conditions: (i) isosmotic (Billard solution) and (ii) hypoosmotic (hatchery water).

We formulated a hypothesis that different sperm motility-activating media have various effects on sperm motility characteristics and oxidative stress, as well as on the protein profiles of rainbow trout sperm. We assumed that an isosmotic solution would have a less serious impact on the sperm parameters examined. Therefore, to test this hypothesis, computer-assisted sperm analysis (CASA), flow cytometry and 2D difference gel electrophoresis (2D DIGE) followed by matrix-assisted laser desorption/ionization time-of-flight/time-of-flight mass spectrometry (MALDI-TOF/TOF) identification were employed to monitor changes in sperm parameters and to identify differentially abundant proteins of sperm activated under isosmotic and hypoosmotic conditions.

\section{Materials and methods}

\section{Animal sampling}

The experiments were carried out on sexually mature spring spawning rainbow trout $(n=7 ; 3+$ years old; weight $=1254 \pm 98 \mathrm{~g}$; total length $=46 \pm 2 \mathrm{~cm}$ ) maintained in the Rutki Salmonid Research Laboratory at the Institute of Inland Fisheries in Olsztyn, Poland. Semen was collecting at the beginning of the spawning season. Prior to milt collection, males were anesthetized using Propiscin (1 ppm; Inland Fisheries Institute, Żabieniec, Poland). Milt from rainbow trout males was obtained by gentle abdominal massage, with special care to avoid contamination with blood, urine or feces. Semen collected from each individual was diluted at a ratio of 1:200 in immobilizing solution for rainbow trout (Morisawa \& Morisawa 1988).

Approval by the Animal Experiments Committee in Olsztyn, Poland (no. 39/2011) was obtained before starting the experiments.

\section{Semen analysis}

Sperm from the same individual, diluted in immobilizing solution, was divided into two aliquots and activated at a dilution ratio of $1: 100$ with: (1) $1 \mathrm{mM} \mathrm{CaCl}, 20 \mathrm{mM}$ Tris, $30 \mathrm{mM}$ glycine and $125 \mathrm{mM} \mathrm{NaCl}$ at a pH of 9.0 (Billard 1992) and (2) 1:100 with hatchery water both supplemented with $0.5 \%$ bovine serum albumin. The motility parameters of sperm were examined with CASA (Hobson Vision Ltd, Baslow, UK), as described in previous studies (Nynca et al. 2014). The following sperm motility parameters were evaluated over a 12-s period, 5-17 s after activation: percentage of motile sperm (MOT), straight-line velocity (VSL), curvilinear velocity $(\mathrm{VCL})$, average path velocity (VAP), linearity (LIN) and the amplitude of lateral head displacement (ALH). Video recordings (two replicates per sample) were obtained using an Olympus BX40 microscope (Olympus Optical) with a 10x negative-phase objective and a Sony CCD black and white camera (SPTM108CE). Sperm concentration and viability were measured using a Muse Cell Analyzer (Millipore) as described by Nynca et al. (2016). The reactive oxygen species (ROS) levels in sperm were estimated using a Muse ${ }^{\circledR}$ Oxidative Stress Kit (EMD Millipore) that simultaneously determines the count and percentage of cells undergoing oxidative stress, based on the intracellular detection of superoxide radicals. The procedure was performed in accordance with the manufacturer's recommendations. To determine accurately the dividing point between $\mathrm{ROS}^{+}$and $\mathrm{ROS}^{-}$populations, a positive control setup was performed by incubating the sperm cells in the presence of $3 \% \mathrm{H}_{2} \mathrm{O}_{2}$, a superoxide anion generator, for $1 \mathrm{~h}$ at RT. Osmolality of seminal plasma was measured using a 5520 Vapor Pressure Osmometer (Wescor, Logan, USA).

\section{Sample preparation}

One minute after activation, semen samples were centrifuged at $3000 \mathrm{~g}$ and $4^{\circ} \mathrm{C}$ for $10 \mathrm{~min}$. After removing the supernatant, the pellets (containing the spermatozoa) were suspended in lysis buffer containing $7 \mathrm{M}$ urea and $2 \mathrm{M}$ thiourea, $2 \%$ CHAPS (3-[(3-cholamidopropyl)dimethylammonio]-1propanesulfonate hydrate) and sonicated using a VCX-130 Ultrasonic Processor (Sonics \& Materials, Inc., Newtown, CT, USA). After incubation for $1 \mathrm{~h}$ at $4^{\circ} \mathrm{C}$, the samples were centrifuged at $12,000 \mathrm{~g}$ for $10 \mathrm{~min}$ at $4^{\circ} \mathrm{C}$. The protein lysates were processed using a Clean-Up Kit (GE Healthcare) according to the manufacturer's protocol. The protein concentration was measured using a Coomassie Plus Kit (Thermo Scientific) with bovine serum albumin as the standard. 


\section{D DIGE analysis and image analysis}

Protein labeling with CyDye DIGE Fluor and 2D electrophoresis slices were performed under the same conditions as described by Nynca et al. (2015). An aliquot of $50 \mu \mathrm{g}$ of protein from each sample of (i) immobilized spermatozoa extract, (ii) spermatozoa extract activated by Billard solution and (iii) spermatozoa activated by hatchery water was dissolved in a labeling buffer (7 M urea, $2 \mathrm{M}$ thiourea, 4\% w/v CHAPS, $30 \mathrm{mM}$ Tris, $\mathrm{pH}$ 8.0) and labeled with CyDye DIGE Fluor minimal dyes (GE Healthcare; reconstituted in fresh $99.8 \%$ anhydrous DMF) at a concentration of $400 \mathrm{pmol}$ dye $/ 50 \mu \mathrm{g}$ of protein. Cy 2 was used to label the internal standard, and Cy 3 and Cy 5 to label individual spermatozoa immobilized and activated by Billard solution and hatchery water sperm samples. A dye swap (Cy3/ Cy5) was performed between activated and immobilized sperm samples to exclude dye bias. An internal standard was created by mixing equal amounts of protein from the immobilized and activated spermatozoa. The labeling reaction was performed in the dark on ice for $30 \mathrm{~min}$. Differentially labeled samples (50 $\mu \mathrm{g}$ each of Cy2-, Cy3- and Cy5-labeled samples) were mixed together, uploaded onto 24-cm IPG strips (pH 3-10 NL), and isoelectric focusing was performed with Ettan IPGphor apparatus (GE Healthcare) as described by Nynca et al. (2015). As a second dimension, a 12.5\% SDS-PAGE (gel size $25.5 \times 19.6 \mathrm{~cm}, 1 \mathrm{~mm}$ thickness; GE Healthcare) was run using Ettan Dalt-Six apparatus (GE Healthcare). The CyDye-labeled gels were analyzed by post-run fluorescence imaging with the use of Typhoon FLA 9400 (GE Healthcare) with parameters recommended for 2D DIGE experiments by the manufacturer. After images were acquired, image analysis was performed using DeCyder Differential Analysis software version 5.02 (GE Healthcare). The number of spots was estimated to the nearest 10,000, and a spot volume of 30,000 was used as a cutoff filter. The DeCyder Biological Variation Analysis module was used to detect protein spots and simultaneously match all 12 protein spot maps from six gels. Protein spots with a $P$ value $<0.05$ by $t$-test analysis that showed at least a 1.3 fold increase or decrease in their relative intensity in any comparison of sperm immobilized and activated by Billard solution or hatchery water were considered as differentially expressed. False discovery rate (FDR) correction was applied when the $t$-test was performed. To properly pick and identify the selected spots, DIGE gels were re-stained using Coomassie Brilliant Blue G-250 (Bio-Rad).

\section{Protein digestion and mass spectrometry protein identification}

Proteins were digested using a trypsin solution (Promega) containing $0.2 \mathrm{mg} / \mathrm{mL}$ trypsin in $15 \mathrm{mM}$ ammonium bicarbonate. Resulting peptide pellets were dissolved in $1 \mathrm{~mL}$ of a $5 \mathrm{mg} / \mathrm{mL}$ solution of $\alpha$-cyano-4-hydroxy-cinnamic acid (Bruker Daltonics, Bremen, Germany) in 50\% acetonitrile and $0.1 \%$ trifluoroacetic acid. MALDI-TOF/TOF analysis was performed using a MALDI TOF tandem mass spectrometer (Autoflex Speed, Bruker Daltonics). The MS together with MS/MS spectra were searched against a NCBInr Bony Fishes database (a database containing 3,005,095 proteins was generated on the 30th January 2017 using the Mascot Server (Matrix Science, London, UK) of the National Center for Biotechnology, in consideration of the following settings): (i) enzyme: trypsin; (ii) fixed modifications: carbamidomethyl; (iii) variable modifications: methionine oxidation; (iv) allow one missed cleavage; (v) peptide tol. $150 \mathrm{ppm}, \mathrm{MS} / \mathrm{MS}$ tol. $0.7 \mathrm{Da}$; (vi) peptide charge 1+; (vii) instrument type: MALDITOF/TOF. The Mascot identity threshold score was defined as 42 for $P<0.05$ Mascot score. In other words, the protein sequence was identified when at least two individual peptides per protein, each of whose probability scores met or exceeded the threshold for statistical significance (ion score $>42$, $P<0.05)$.

\section{Ontology and ingenuity pathway analyses of the identified proteins}

Gene ontology (GO) annotation was acquired by matching the GI numbers of identified proteins to the UniProtKB database (www.uniprot.org). The category used was 'molecular functions'. Ingenuity Pathway Analysis (IPA; Qiagen Silicon Valley) of the identified proteins used the Core Analysis function to interpret the identified proteins in the context of biological functions and pathways. Because IPA only accepts gene or protein accession numbers representing human, mouse and rat genes or proteins, orthologs of the identified rainbow trout proteins belonging to those three species were first identified, and the accession numbers of the top blast hits were uploaded to IPA. The significance of biological functions and canonical pathways was tested automatically by the software, with use of the Fisher's exact test $P$ value. Top significant functions and canonical pathways were selected by the software for each tested proteome. Additionally, the proteins with larger expression (greater than 2-fold change) after hypoosmotic activation were analyzed by g:Profiler (https://biit.cs.ut.ee/gprofiler/gost).

\section{Statistical analysis}

All the results of the semen parameters are presented as means \pm S.D. For statistical procedures, percentage data for sperm motility parameters were transformed by arcsin square-root transformation. The sperm motility parameters data were subjected to a Student's $t$-test for paired samples; data regarding sperm viability and ROS-positive cell content were subjected to one-way ANOVA followed by Tukey's multiple comparisons test. All analyses were performed at a significance level of 0.05 using GraphPad Prism software (GraphPad Software Inc.).

\section{Results}

\section{Effect of activation solution on sperm motility parameters, viability and ROS}

The two activation solutions affected sperm motility parameters in a different manner (Fig. 1A, B, C, D, E and $F$ ). Activation with Billard solution resulted in higher values $(P \leq 0.05)$ for sperm motility parameters 

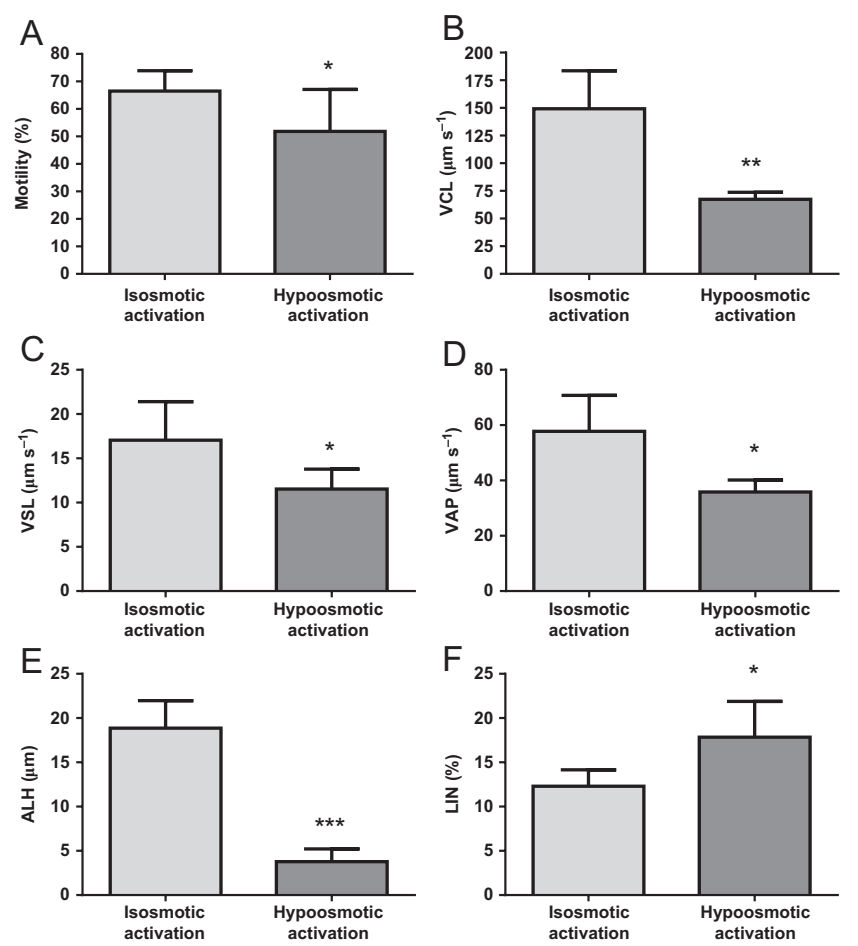

Figure 1 Effect of isosmotic and hypoosmotic activation on sperm motility parameters of rainbow trout $(n=7)$. (A) Percentage of sperm motility, (B) VCL (curvilinear line velocity), (C) VSL (straight line velocity), (D) VAP (average path velocity), (E) ALH (amplitude of lateral head displacement), (F) LIN (linearity). Results are expressed as means \pm S.D. Asterisk indicates significant differences between parameters for activated sperm in isosmotic and hypoosmotic conditions $\left(* P<0.05,{ }^{* *} P<0.01 ;{ }^{* * *} P<0.001\right)$.

except LIN, for which lower values were noticed in comparison to activation of sperm with hatchery water (Fig. 1F). Different activation solutions used for sperm activation had no effect on sperm viability (Fig. 2A), but significantly $(P \leq 0.05)$ increased the proportion of ROS-positive cells, that reached $19.4 \%$ for semen activated with $\mathrm{H}_{2} \mathrm{O}$. At the same time, the increase by 9.5\% was not significant for the activation with Billard solution (Fig. 2B). The average sperm concentration and
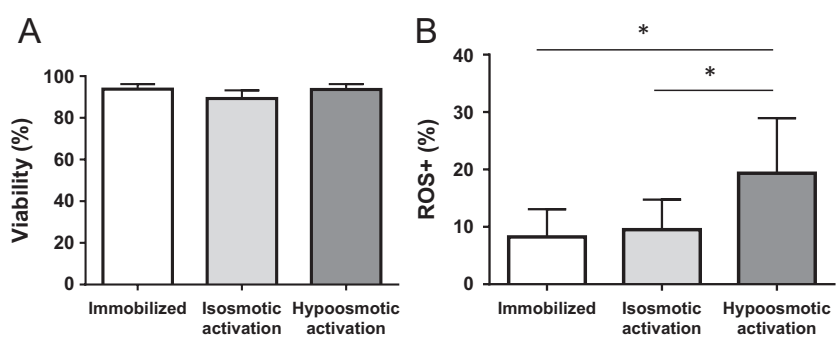

Figure 2 Effect of sperm activation on viability (A) and ROS-positive cell content of rainbow trout semen (B) $(n=7)$. Results are expressed as means \pm S.D. Asterisk indicates significant differences between ROS-positive cell content for immobilized and activated sperm in isosmotic and hypoosmotic conditions $(P<0.05)$. osmolality of samples used for the experiment were $11.7 \pm 3.3 \times 10^{9} / \mathrm{mL}$ and $280 \pm 9 \mathrm{mosmol} / \mathrm{kg}$, respectively.

\section{Comparison of immobilized and activated sperm proteome}

The analysis of sperm immobilized and activated with hatchery water using 2D DIGE technology led to the detection of 1260 matched spots and 61 spots with a significant difference $(P \leq 0.05)$ in their relative abundance between immobilized and activated sperm (Fig. 3A and B, Supplementary Table 1, see section on supplementary data given at the end of this article). Thirty-nine spots were enriched in sperm activated with $\mathrm{H}_{2} \mathrm{O}$, and 22 spots were more abundant in immobilized sperm. Out of 38 spots with a greater abundance in $\mathrm{H}_{2} \mathrm{O}$-activated sperm, 30 spots were identified by MALDI-TOF/TOF, whereas out of 23 spots upregulated in immobilized sperm, 20 spots were identified (Table 1, Supplementary Table 2). Amongst identified proteins 13 proteins have been identified with higher expression, the cAMP-dependent protein kinase type II was the protein which most increased in response to hypoosmotic activation (fold change 3.53), whereas cilia- and flagellaassociated protein 58 was the most downregulated (fold change -5.26$)$. The 22 proteins were characterized by small changes in expression $(-1.4>$ and $<1.4)$.

Isosmotic activation led to the detection of two spots with a significant difference in their relative abundance when compared to immobilized sperm (Fig. 3C and D). Those spots (nos. 44 and 47) corresponded to spots with a higher abundance in $\mathrm{H}_{2} \mathrm{O}$-activated sperm (Table 2).

\section{GO annotation and signaling pathway analysis of differentially abundant proteins}

The 50 proteins identified with a change in abundance in sperm activated with hatchery water were classified according to the 'molecular function' GO database (Fig. 4). Based on molecular function analysis, proteins were divided into four groups, with the majority having binding and catalytic activity (Fig. 4).

A summary of all associated pathways, annotated using IPA, for proteins differentially abundant in immobilized and activated sperm is provided in Table 3. The top canonical pathways associated with proteins changed during sperm activation include the TCA cycle, tight and gap junction signaling, Sertoli cell-Sertoli cell junction signaling and asparagine degradation, while the molecular and cellular functions include amino acid metabolism, small-molecule biochemistry, cellular function and maintenance, cellular movement, assembly and organization (Table 3). From a list of top networks generated using IPA, for further analysis we selected the most representative network associated with the functions that were more pertinent to the sperm activation such as cellular movement (Fig. 5). 

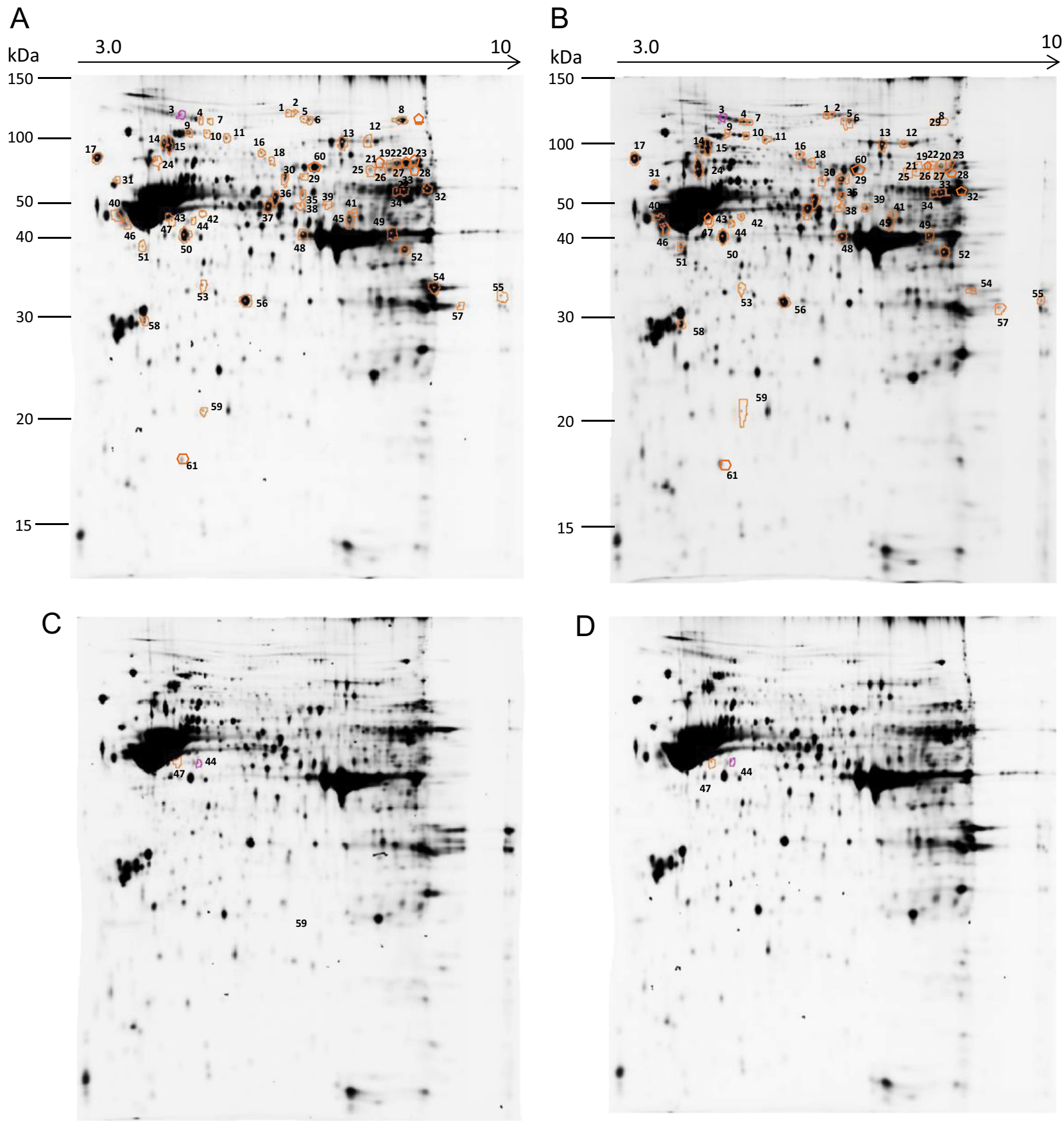

Figure 32 D DIGE analysis of immobilized and activated rainbow trout spermatozoa. Numbered protein spots (1-61) correspond to proteins identified from 2D DIGE which changed in abundance after activation of immobilized sperm (A) in hypoosmotic conditions (B). Numbered protein spots $(44,47)$ correspond to proteins identified from 2D DIGE which changed in abundance after activation of immobilized sperm $(C)$ in isosmotic conditions (D). The nonlinear $\mathrm{pH}$ range of the first-dimension IPG strip is indicated along the top of the gel, acidic $\mathrm{pH}$ to the left. The MW (relative molecular mass) scale can be used to estimate the molecular weights of the separated proteins.

The network with a score of 38, in which 11 proteins show increasing trends expression during activation (EFHC1, EFHC2, TEKT2, DNAI2, PRKAR2A, TUBB4B, SPAG6, CCDC40, CABYR, OGDH, ACAT1) and 5 proteins were decreased. Most of the sperm proteins displaying a change in level after motility activation are closely connected in the network through nodes $\mathrm{Ca}^{2+}$ and PRKAR2A being reported to be involved in sperm motility (Itoh et al. 2003, Dietrich et al. 2016). A majority of proteins were observed to be cytoplasmic in origin. They were involved in functions related to enzyme activity, kinase, peptidase, the G-protein-coupled 


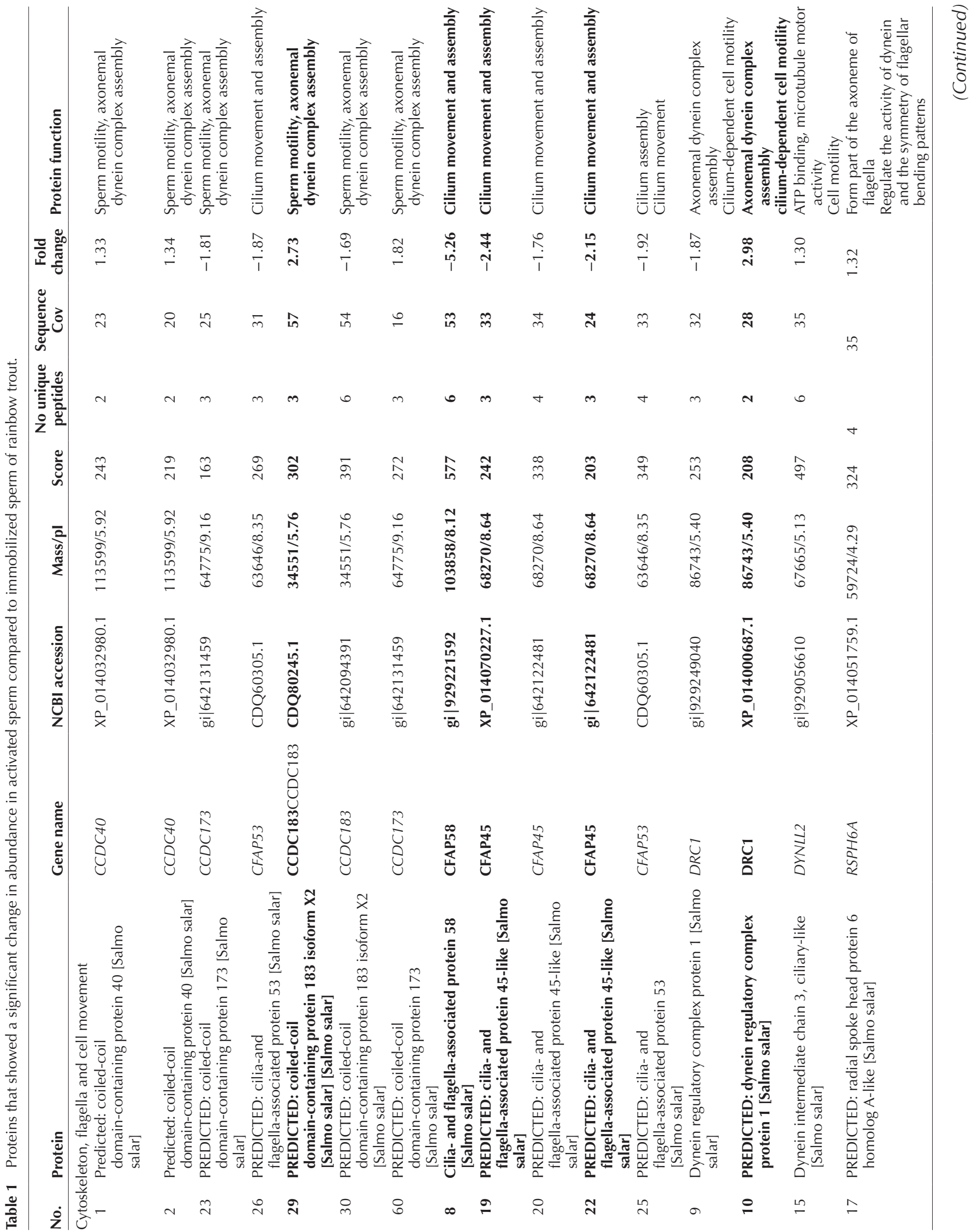




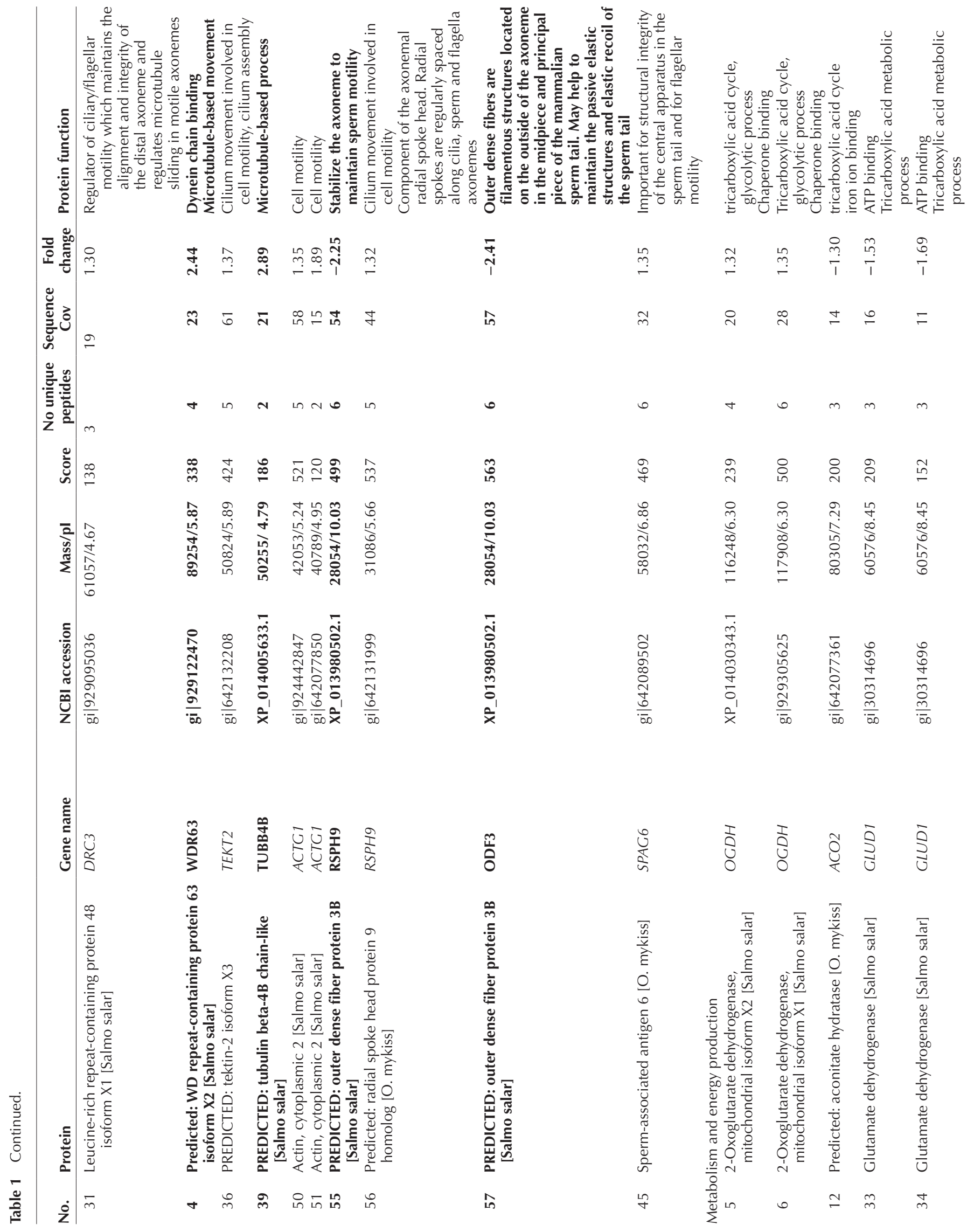




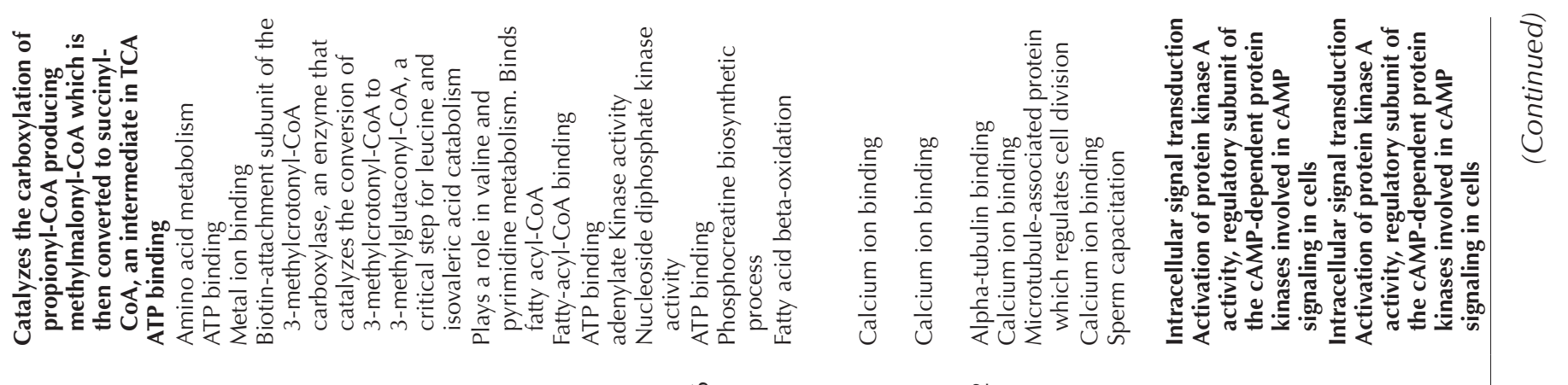




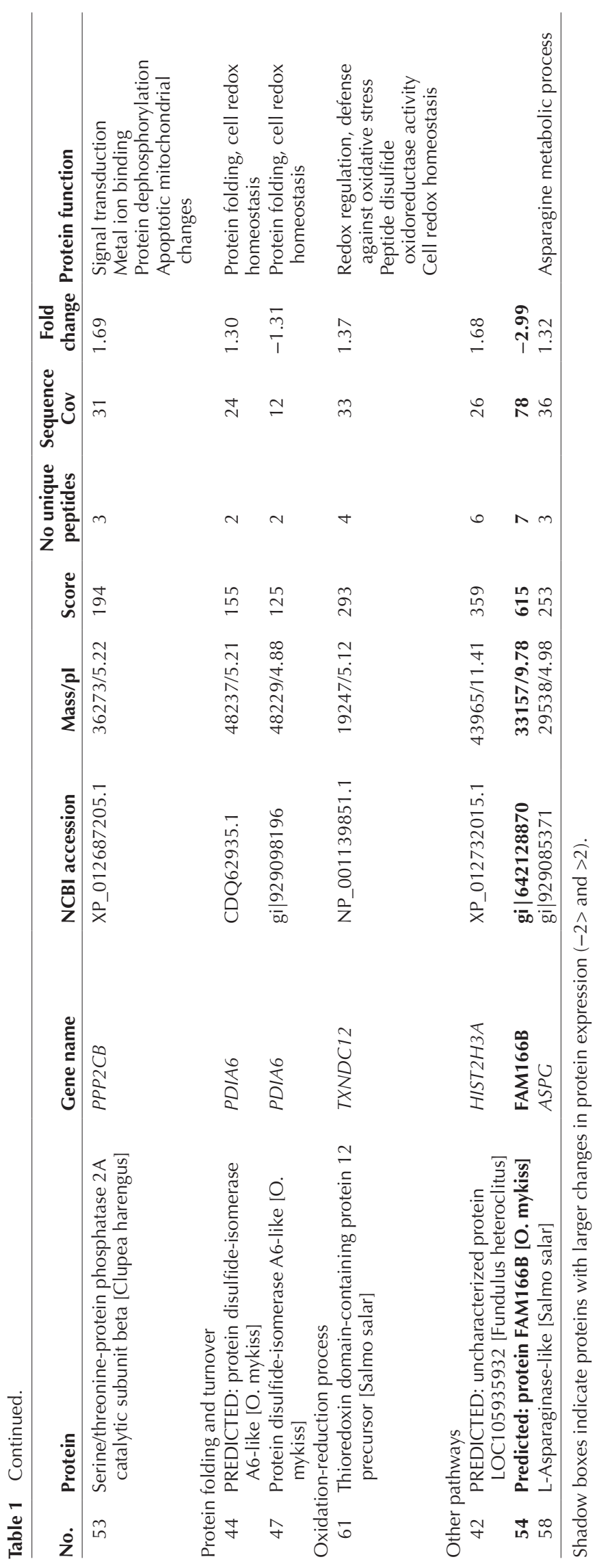

receptor, growth factor and transcription regulator. The proteins with larger expression after hypoosmotic activation were analyzed by g:Profiler in terms of their biological process and cellular component. Axoneme assembly and microtubule formation were found as top biological process.

\section{Discussion}

This is the first comparative study of the impact of different activation media (isosmotic, hypoosmotic) on rainbow trout sperm characteristics including sperm motility parameters, viability, oxidative stress and protein profile. Spermatozoa activation with hatchery water was associated with lower values for sperm motility parameters and an induced increase in ROS level in comparison to Billard solution activation. The application of a 2D DIGE approach revealed a higher number of differentially abundant sperm proteins after activation with hatchery water and facilitated the identification of 50 protein spots. On the other hand, activation with Billard solution led to the identification of only two spots changed in response to activation which were also changed after activation with hatchery water. The 50 differentially abundant proteins in activated sperm were involved in a variety of pathways including the TCA cycle, tight and gap junction signaling, Sertoli cell-Sertoli cell junction signaling and asparagine degradation.

\section{Motility parameters and model}

In externally fertilizing species, osmolality of the fertilization medium is known to play a critical role in activating sperm motility; exposure to a hypoosmotic environment triggers the initiation of salmonid fish sperm motility (Alavi \& Cosson 2006). In our study, osmolality of the activation medium (Billard solution, hatchery water) clearly affected the sperm motility parameters in a different manner. Sperm motility activated with Billard solution resulted in mostly higher values of CASA parameters compared to activation of sperm with hatchery water. These results clearly demonstrate the different action of osmolality on spermatozoa motility, since Billard solution is isosmotic to seminal plasma (approximately $300 \mathrm{mosmol} / \mathrm{kg}$ ), whereas $\mathrm{H}_{2} \mathrm{O}$ is hypoosmotic (low osmolality medium, below $50 \mathrm{mosmol} / \mathrm{kg}$ ). Summing up, the CASA analysis results allowed us to clearly distinguish two modes of sperm activation in rainbow trout and verified our experimental model which was a prerequisite for our study.

\section{Viability is not affected by osmotic stress}

Under the conditions of our experimental design, we did not observe significant changes in viability. It is well known that low osmolality induces sperm cell swelling, 
Table 2 Proteins that showed a significant change in abundance in isosmotic activated sperm compared to immobilized sperm of rainbow trout.

\begin{tabular}{|c|c|c|c|c|c|c|c|c|c|}
\hline No. & Protein & $\begin{array}{l}\text { Gene } \\
\text { name }\end{array}$ & $\begin{array}{l}\text { NCBI } \\
\text { accession }\end{array}$ & Mass/pl & Score & $\begin{array}{l}\text { No unique } \\
\text { peptides }\end{array}$ & $\begin{array}{l}\text { Sequence } \\
\text { Cov }\end{array}$ & $\begin{array}{l}\text { Fold } \\
\text { change }\end{array}$ & Protein function \\
\hline \multicolumn{10}{|c|}{ Protein folding and turnover } \\
\hline 44 & $\begin{array}{l}\text { PREDICTED: protein } \\
\text { disulfide-isomerase } \\
\text { A6-like [O. mykiss] }\end{array}$ & PDIA6 & CDQ62935.1 & $48237 / 5.21$ & 155 & 2 & 22 & 1.43 & $\begin{array}{r}\text { Protein folding, cell } \\
\text { redox homeostasis }\end{array}$ \\
\hline 47 & $\begin{array}{l}\text { Protein disulfide-isomerase } \\
\text { A6-like [O. mykiss] }\end{array}$ & PDIA6 & gi|929098196 & $48229 / 4.88$ & 125 & 2 & 14 & -1.51 & $\begin{array}{l}\text { Protein folding, cell } \\
\text { redox homeostasis }\end{array}$ \\
\hline
\end{tabular}

and disruption of the plasma membrane occurs due to the large osmotic shock (Morisawa et al. 1983). However, in our study, serious disruption of spermatozoa likely did not occur, because different osmolality of the activating medium led to the activation of rainbow trout sperm motility, but without affecting the viability of spermatozoa. It is well known that the application of activating isosmotic media during artificial fertilization of salmonids leads to higher fertilization rate (Billard 1992) compared to hypoosmotic hatchery water. The dilution of trout sperm in a saline solution (Billard solution) resulted in about $80 \%$ fertilization rate in comparison to dilution in fresh water where about $60 \%$ of fertilization was achieved (Billard 1990). These solutions not only positively affect spermatozoa motility and prolong the time during which eggs can be fertilized due to reduced osmotic shock but also prevent the harmful effects of pollution by yolk released from broken oocytes which might block the micropyle of eggs (Billard 1992).

\section{Osmotic stress causes oxidative stress}

In our study, we have observed a clear difference between sperm activated in water and in Billard solution regarding ROS-positive cell content. Our results indicate that sperm activation with hatchery water causes an increase in ROS production and induces greater changes in sperm protein profile (see below) compared to Billard activation. This strongly suggests

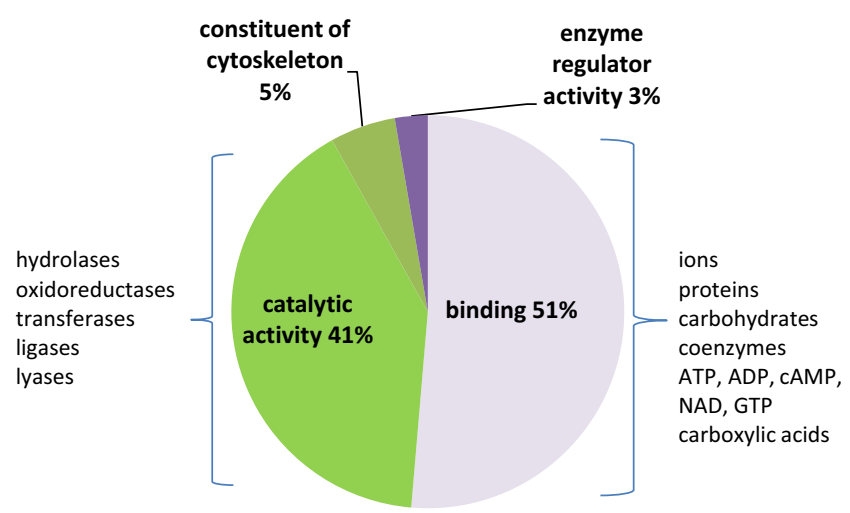

Figure 4 Gene ontology annotations for rainbow trout sperm proteins according to the GO term 'molecular function'. that osmotic stress induces an oxidative stress in fish spermatozoa activated with water. Such a phenomenon has been described for mammals (Burnaugh et al. 2010, McCarthy et al. 2010), and recently the phenomenon has also been suggested for fish. Dietrich et al. (2016) recorded changes in oxidative proteins (peroxiredoxin and glutathione-S-transferase) during activation of carp sperm motility in water. This suggests that antioxidant enzymes play a vital role in coping with oxidative stress caused by osmotic stress. Dzyuba et al. (2016) recorded higher levels of thiobarbituric acid reactive substances (TBARS, an indicator of lipid peroxidation) in tench spermatozoa activated at $0 \mathrm{mosmol} / \mathrm{kg}$ compared to non-activated sperm. These authors also observed an increase in TBARS due to activation at $100 \mathrm{mosmol} /$ $\mathrm{kg}$, although this increase was not significant. In our study, we did not observe ROS production in sperm activated with Billard solution which is isosmotic for fish. Altogether, our results and those of Dietrich et al. (2016) and Dzyuba et al. (2016) collectively suggest that, in fish, osmotic stress which triggers activation of sperm motility causes oxidative stress at the same time. More detailed further studies are necessary to test the kinetics between osmotic stress and oxidative stress in order to unravel the links between the mechanisms of osmotic and oxidative stress.

\section{Superoxide anion seems not to be important in activation of sperm motility in rainbow trout}

Our results strongly suggest that, contrary to hypotonic activation, isosmotic activation of sperm motility in rainbow trout is not accompanied by substantial oxidative stress caused by ROS, because no significant increase in ROS-positive spermatozoa was observed in spermatozoa activated with Billard's solution. This result was not expected in view of the postulated role of ROS in sperm activation, including in fish (de Lamirande \& O'Flaherty 2008, Dzyuba \& Cosson 2014, Pereira et al. 2017). However, it should be stressed that the Muse Oxidative Stress Kit is based on the use of dihydroethidium (DHE), a well-characterized reagent that has been extensively used to detect ROS in cellular populations (Anonymous 2013). This reagent is specific for superoxide anion but no other oxidizing species such as $\mathrm{H}_{2} \mathrm{O}_{2}$, hypochlorous acid or peroxynitrite (Fink et al. 2004). Therefore, it can 
Table 3 Functional analysis of sperm proteins changed in response to activation in hypoosmotic conditions.

\begin{tabular}{|c|c|c|c|c|c|c|}
\hline Top canonical pathways & $P$-Value* & Molecules & $\begin{array}{l}\text { Molecular and } \\
\text { cellular functions }\end{array}$ & $P$-Value* & Top networks & Score** \\
\hline TCA cycle & $6.45-04$ & $\mathrm{OGDH}, \mathrm{ACO} 2$ & $\begin{array}{l}\text { Amino acid } \\
\text { metabolism }\end{array}$ & $2.91 \mathrm{E}-02-1.05 \mathrm{E}-07$ & $\begin{array}{l}\text { Cellular movement, reproductive } \\
\text { system development and } \\
\text { function, cellular function and } \\
\text { maintenance }\end{array}$ & 38 \\
\hline Tight junction signaling & $2.55 \mathrm{E}-03$ & $\begin{array}{l}\text { ACTG1, PPP2CB, } \\
\text { PRKAR2A }\end{array}$ & $\begin{array}{l}\text { Small molecule } \\
\text { biochemistry }\end{array}$ & 2.91E-02-1.05E-07 & Post-translational modification & 27 \\
\hline Gap junction signaling & $2.73 \mathrm{E}-03$ & $\begin{array}{l}\text { ACTG1, TUBB4B, } \\
\text { PRKAR2A }\end{array}$ & $\begin{array}{l}\text { Cellular function } \\
\text { and maintenance }\end{array}$ & $1.14 \mathrm{E}-02-2.54 \mathrm{E}-05$ & Molecular transport & 7 \\
\hline $\begin{array}{l}\text { Sertoli cell-Sertoli Cell } \\
\text { junction signaling }\end{array}$ & $3.06 \mathrm{E}-03$ & $\begin{array}{l}\text { ACTG1, TUBB4B, } \\
\text { PRKAR2A }\end{array}$ & Cellular movement & $9.68 \mathrm{E}-04-2.54 \mathrm{E}-05$ & & \\
\hline Asparagine degradation I & $3.27 \mathrm{E}-03$ & ASPG & $\begin{array}{l}\text { Cellular assembly } \\
\text { and organization }\end{array}$ & $2.27 \mathrm{E}-02-5.09 \mathrm{E}-04$ & & \\
\hline
\end{tabular}

*The $P$-value associated with a function or a pathway is a measure of the likelihood that the association between a set of focus genes in the experiment and a given process or pathway is due to random chance. The smaller the $P$-value the less likely that the association is random and the more significant the association. In general, a $P$ value (calculated using the right-tailed Fisher exact test) $<0.05$ indicates a statistically significant, nonrandom association. ${ }^{* *}$ The score is derived from a $P$-value and indicates the likelihood of the Focus Genes in a network being found together due to random chance. The score takes into account the number of focus genes in the network and the size of the network to approximate how relevant this network is to the original list of focus genes.

ACO2, aconitate hydratase; ACTG1, actin, cytoplasmic 2; ASPG, L-asparaginase; OGDH, 2-oxoglutarate dehydrogenase; PP2CB, serine/ threonine-protein phosphatase 2A catalytic subunit beta; PRKAR2A, CAMP-dependent protein kinase type II-alpha; TUBB4B, tubulin beta-4B.

be suggested that superoxide anion is not important in the activation of sperm motility in trout. Perhaps other reactive species are more important for the activation of sperm motility, such as peroxynitrite and its precursor nitric oxide. The latter has been postulated to be involved in sperm motility of fathead minnow (Creech et al. 1998), catfish (Barman et al. 2013) and steelhead (Wilson-Leedy \& Ingermann 2011).

\section{Only a single protein changed after isosmotic activation}

Remarkably, contrary to hypotonic activation, only one protein responded to the activation in isosmotic conditions - protein disulfide-isomerase 6 (PDI6). This finding was not expected because we rather anticipated changes in proteins involved in the sperm motility apparatus and sperm metabolism which are the most important characteristics of motile spermatozoa. PDI is involved in correct folding of the proteins through oxidation, reduction and isomerization of disulfide bonds. PDI is a member of the thioredoxin superfamily and can act as an oxidant by forming intra-chain disulfide bonds, which leads to the acquisition of proper conformation by proteins (Yoshioka 2015). To fulfill this function, PDI occurs either in an oxidized or reduced state. In human spermatozoa, PDI6 is located in the peri-acrosomal region, has been associated with chaperone activity and capacitation (Bromfield et al. 2016) and has been postulated as a fertility marker (Schorr-Lenz et al. 2016). No evidence for the possible mechanisms of PDI6 action in fish sperm is available but it seems to be clear that involvement in cell signaling has to be part of such a mechanism. This suggestion is supported by the involvement of PDI in numerous redox cell-signaling actions through regulation of thiol-disulfide switches, including those on the cell surface (Laurindo et al. 2012). Most importantly, it has been found that peroxynitrite can oxidize and specifically regulate PDI (Peixoto et al. 2018). This agrees with the postulated role of peroxynitrite in the activation of sperm movement (see section on Superoxide anion seems not to be important in activation of sperm motility in rainbow trout). PDI has also been found to be a target for protein S-nitrosylation in human spermatozoa (Lefièvre et al. 2007). Altogether, the information presented clearly demonstrates the involvement of PDI in the signaling mechanisms of the cells. This opens an exciting area of research aimed at testing the possible involvement of PDI in activation of sperm motility in salmonid fish, and possibly in other fish species as well, in view of identification of PDI during activation of carp spermatozoa (Dietrich et al. 2016).

The exact mechanism concerning an increase of PDI abundance in response to activation of sperm motility is unknown at present. Obviously, PDI biosynthesis must be ruled out because of the extremely short time of activation. Moreover, translation in spermatozoa is absent or extremely restricted due to compaction of the haploid genome. It is likely that changes in PDI conformation are rather related to post-translational modifications (PTMs). Indeed, several PTMs have been reported for PDI, including S-nitrosylation, glutathionylation, phosphorylation, arginylation, cleavage, 4-hydroxynonenal addition, O-linked $\mathrm{N}$-acetylglucosamine addition and metal binding (Laurindo et al. 2012). Identification of specific PTMs in rainbow trout PDI and the precise functions of such modifications need to be validated in further studies, which may be critical for better understanding of sperm motility activation in salmonid fish. 


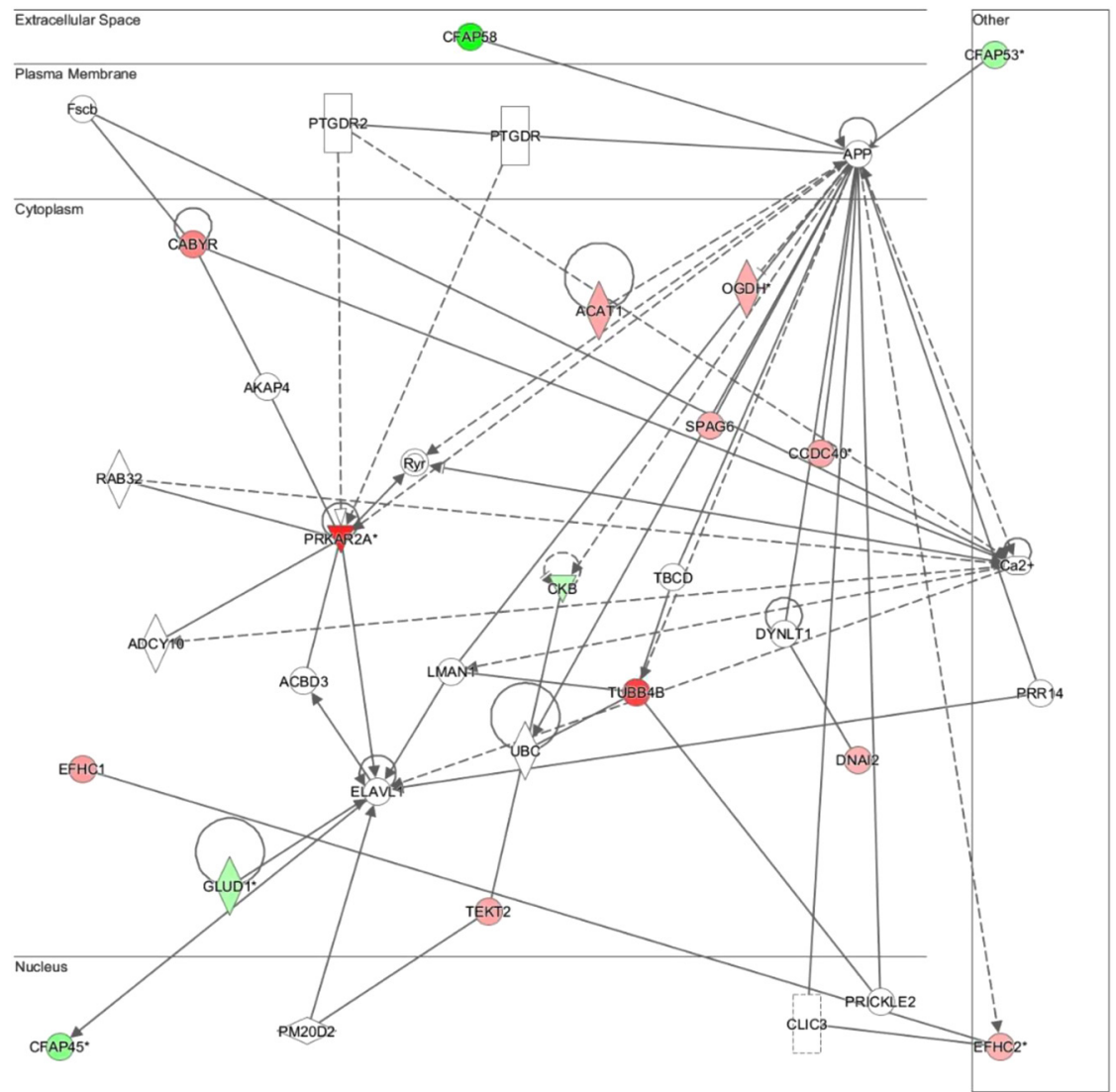

Figure 5 Cellular movement as signaling pathways associated with rainbow trout sperm motility activation. Red denotes proteins that increased after sperm motility activation, while green denotes proteins that decreased after sperm motility activation. Color intensity indicates expression level. The proteins filled in 'red' and 'green' are the ones identified in our study while the remaining ones are the proteins in the Ingenuity Knowledge Base that interact with ours (unfilled were added by IPA software to complete the pathway). Lines indicate interactions, with the arrowheads indicating directionality. Absence of arrowheads refers to a binding interaction. Dotted line indicates an inferred or indirect interaction. Nodes are represented with various shapes to distinguish the functional class of the molecule: $\diamond$ enzyme, $\square$ G-protein coupled receptor, $\square$ growth factor, $\nabla$ kinase, $\diamond$ peptidase, transcription regulator, $\bigcirc$ group or complex, $\bigcirc$ other.

\section{Greater changes in protein abundance after hypoosmotic activation}

In our study, after activation with hatchery water, the sperm proteome changed to a greater extent in comparison to Billard solution activation. Extensive changes in protein abundance of sperm after hatchery water activation are likely to be the results of osmotic and oxidative stress. Osmotic stress leads to damage

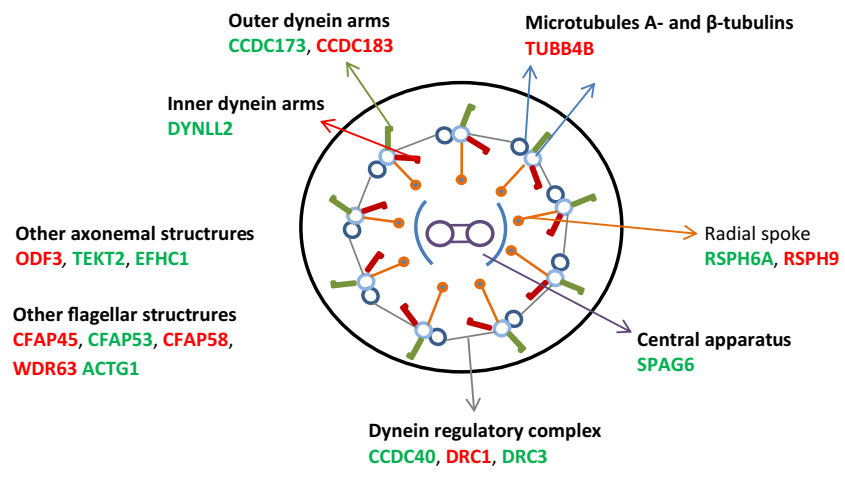

Figure 6 Substructures comprising sperm flagellar axoneme with marked identified proteins changed after activation in hypoosmotic conditions. Proteins that show marked changes $(-2>$ and $>2)$ in expression are shown in red. Proteins that show minor changes $(-2<$ and $<2$ ) in expression are shown in green. of the plasma membrane and alteration in sperm metabolism. ROS can damage cell structures such as carbohydrates, nucleic acids, lipids and proteins and alter their functions (Birben et al. 2012). Subsequent alterations in protein conformation can lead to increased aggregation, fragmentation, distortion of secondary and tertiary structure, and susceptibility to proteolysis and diminution of normal function (Butterfield et al. 1998). In turn, oxidative stress may lead to alterations in protein expression levels in spermatozoa, causing molecular and genetic defects and impairing male fertility (Morielli \& O'Flaherty 2015). In our study, the decrease in protein abundance after motility activation with water could also be the result of leakage of proteins from spermatozoa. On the other hand, an increase in protein abundance could be linked with PTMs and activation of proproteins by restricted proteolysis, as was postulated for mammalian spermatozoa (Kwon et al. 2014, Westfalewicz et al. 2015). In our study the most extensive changes in protein abundance after hypoosmotic activation were found for cAMP-dependent protein kinase (fold change 3.53) and for cilia- and flagella-associated protein 58 (fold change -5.26). Those proteins are involved in sperm motility. The cyclic AMP-dependent phosphorylation of proteins is essential for the initiation of sperm motility in salmonid fishes, whereas cilium- and flagellum-specific proteins play a role in axonemal structure organization and motility. 


\section{Hypoosmotic activation affected mostly proteins related to cytoskeleton, flagella and cell movement}

A plethora of sperm proteins changed after hatchery water activation were found to be associated with cell movement. Their potential localization is shown in Fig. 6. These proteins are constituents of several structures of flagella including outer and inner dynein arms, microtubules, radial spoke, central apparatus, dynein regulatory complex and other axonemal structures and contribute to the stability of spermatozoa and formation of flagella, and therefore, play an important role in sperm motility (Baltz et al. 1990, Inaba et al. 1998). For example, coiled-coil domain proteins interact with the motor protein kinesin, which in turn participates in axoneme formation in the sperm flagellum (Lehti et al. 2013). Tektins are involved in the formation of sperm flagella; they are necessary for the proper coordinated beating of the sperm flagellum and are required for progressive sperm motility (Roy et al. 2009). Actin and tubulin participate in flagellar motility by dynein-driven microtubule sliding. In turn, dynein regulatory proteins are involved not only in the structural maintenance of flagellar elasticity but also play a regulatory role in flagellar motility (Si \& Okuno 1993). Identification of tubulin and dynein is in agreement with data obtained by Dietrich et al. (2016) for common carp activation in hypoosmotic conditions. Taken together, the activation of sperm motility in rainbow trout and possibly other freshwater fish is associated with profound changes in the structural components of sperm flagella. The number of significant changes in the sperm proteome related to the cytoskeleton, flagella and cell movement strongly suggest dynamic changes in the sperm motility apparatus in response to activation of movement in hypoosmotic conditions. On the other hand, some of these changes could reflect negative effects related to osmotic stress, which results in lower quality of movement compared to activation in isosmotic conditions.

\section{Hypoosmotic activation affects proteins associated with metabolism}

The changes occurring within the proteome observed after sperm motility activation in hypoosmotic conditions are associated with changes in proteins related to metabolism and energy production. Categorization of proteins according to molecular function indicates that the majority of proteins are involved in catalytic activity and binding. In this study, we identified spermatozoa proteins involved in glycolysis, the TCA cycle (indicated as a top canonical pathway by IPA), the fatty acid cycle, amino acid metabolism (indicated as a key molecular and cellular function by IPA) and ATP binding. Those results agree with previous findings indicating the importance of lipid metabolism and glycolysis for energy provision in sperm (Lahnsteiner et al. 1993, 1999). Maintenance of ATP level during motility is initiated and provided by the hydrolysis of ATP which can be provided by the creatine kinase identified in our study. As seminal plasma and spermatozoa of rainbow trout exhibit enzyme activity to catabolize amino acids, they might serve as additional energy resources, especially for sperm motility activation (Lahnsteiner et al. 2009). Summarizing, the involvement of different enzymes associated with several energy production pathways and ATP production in spermatozoa likely agrees with the high and quick energy requirements for the initiation of fish sperm motility. Similar to changes in structural proteins, disturbances to metabolic enzymes could be a consequence of osmotic stress and be part of the mechanism resulting in lower quality of movement in hypoosmotic conditions.

Besides several proteins involved in sperm structure and metabolism, we have detected proteins engaged in other functions, including $\mathrm{Ca}^{2+}$ binding, signal transduction, protein folding and turnover. Since $\mathrm{Ca}^{2+}$ ions are necessary for triggering the motility of rainbow trout (Cosson et al. 1989), $\mathrm{Ca}^{2+}$-binding proteins could be responsible for the mobilization of calcium ions in sperm. Disturbance of proteins involved in antioxidant protection might impair the scavenging or detoxifying of excess ROS in rainbow trout sperm during activation in hypoosmotic conditions indicated in this study, which leads to lower sperm motility parameters. In turn, signal transduction proteins could participate in initiation of sperm motility mediated by CAMP signaling pathways and serine/threonine-protein phosphatase $2 \mathrm{~A}$, which is known to regulate dynein phosphorylation in salmonids (Inaba 2002). Detailed roles of the proteins indicated need to be studied in further comprehensive studies.

Summing up, our results clearly demonstrate the different action of osmolality on rainbow trout spermatozoa motility. Activation in isosmotic conditions results in a higher quality of sperm movement in comparison to hypoosmotic conditions. During hypoosmotic activation of sperm motility with hatchery water, osmotic stress triggers oxidative stress and disturbances to structural proteins and metabolic enzymes. Sperm cells seem to be well protected in isosmotic conditions against osmotic and oxidative stress. Our results strongly suggest that comparative physiological and biochemical analysis of rainbow trout sperm characteristics in isosmotic and hypoosmotic conditions could be a useful model for studying the mechanism of sperm activation in salmonid fish.

\section{Supplementary data}

This is linked to the online version of the paper at https://doi.org/10.1530/REP-19-0012. 


\section{Declaration of interest}

The authors declare that there is no conflict of interest that could be perceived as prejudicing the impartiality of the research reported.

\section{Funding}

This work was supported by Project 2015/17/B/NZ9/01542 from the National Science Centre, as well as funds appropriated to the Institute of Animal Reproduction and Food Research, Polish Academy of Sciences.

\section{References}

Alavi SMH \& Cosson J 2006 Sperm motility in fishes. (II) Effects of ions and osmolality: a review. Cell Biology International 30 1-14. (https://doi. org/10.1016/j.cellbi.2005.06.004)

Anonymous 2013 Muse ${ }^{\circledast}$ Oxidative Stress Kit, User's Guide. EMD. Millipore Corporation.

Baltz JM, Williams PO \& Cone RA 1990 Dense fibres protect mammalian sperm against damage. Biology of Reproduction 43 485-491. (https:// doi.org/10.1095/biolreprod43.3.485)

Barman AS, Kumar P, Mariahabib LKK, Lal KK \& Lal B 2013 Role of nitric oxide in motility and fertilizing ability of sperm of Heteropneustes fossilis (Bloch.). Animal Reproduction Science 137 119-127. (https://doi. org/10.1016/j.anireprosci.2012.12.001)

Billard R 1978 Changes in structure and fertilizing ability of marine and freshwater fish spermatozoa diluted in media of various salinities. Aquaculture 14 187-198. (https://doi.org/10.1016/00448486(78)90094-7)

Billard R 1990 Artificial insemination in fish. In Marshall's Physiology of Reproduction, pp 870-888. Ed GE Lamming. Edinburgh: Churchill Livingstone.

Billard R 1992 Reproduction in rainbow trout: sex differentiation, dynamics of gametogenesis, biology and preservation of gametes. Aquaculture $\mathbf{1 0 0}$ 263-298. (https://doi.org/10.1016/0044-8486(92)90385-X)

Billard R \& Cosson MP 1990 The energetics of fish motility. In Control of Sperm Motility: Biological and Clinical Aspects, pp 153-173. Ed C Gagnon. Boston: CRC Press.

Billard R \& Cosson MP 1992 Some problems related to the assessment of sperm motility in freshwater fish. Journal of Experimental Zoology $\mathbf{2 6 1}$ 122-131. (https://doi.org/10.1002/jez.1402610203)

Birben E, Sahiner UM, Sackesen C, Erzurum S \& Kalayci O 2012 Oxidative stress and antioxidant defense. World Allergy Organization Journal 5 9-19. (https://doi.org/10.1097/WOX.0b013e3182439613)

Bromfield EG, McLaughlin EA, Aitken RJ \& Nixon B 2016 Heat shock protein member A2 forms a stable complex with angiotensin converting enzyme and protein disulfide isomerase A6 in human spermatozoa. Molecular Human Reproduction 22 93-109. (https://doi.org/10.1093/molehr/ gav073)

Burnaugh L, Ball BA, Sabeur K, Thomas AD \& Meyers SA 2010 Osmotic stress stimulates generation of superoxide anion by spermatozoa in horses. Animal Reproduction Science 117 249-260. (https://doi. org/10.1016/j.anireprosci.2009.05.014)

Butterfield DA, Koppal T, Howard B, Subramaniam R, Hall N, Hensley K, Yatin S, Allen K, Aksenov M, Aksenova M et al. 1998 Structural and functional changes in proteins induced by free radical-mediated oxidative stress, and protective action of the antioxidants N-tert-butylalpha-phenylnitrone and vitamin E. Annals of the New York Academy of Sciences 854 448-462. (https://doi.org/10.1111/j.1749-6632.1998. tb09924.x)

Cosson MP, Billard R \& Letellier L 1989 Rise of internal Ca2+ accompanies the initiation of trout sperm motility. Cell Motility and the Cytoskeleton 14 424-434. (https://doi.org/10.1002/cm.970140312)

Creech MM, Arnold EV, Boyle B, Muzinich MC, Montville C, Bohle DS \& Atherton RW 1998 Sperm motility enhancement by nitric oxide produced by the oocytes of fathead minnows, Pimephelas promelas. Journal of
Andrology 19 667-674. (https://doi.org/10.1002/j.1939-4640.1998. tb02076.x)

de Lamirande E \& O'Flaherty C 2008 Sperm activation: role of reactive oxygen species and kinases. Biochimica et Biophysica Acta 1784 106-115. (https://doi.org/10.1016/j.bbapap.2007.08.024)

Dietrich MA, Dietrich GJ, Mostek A \& Ciereszko A 2016 Motility of carp spermatozoa is associated with profound changes in the sperm proteome. Journal of Proteomics 138 124-135. (https://doi.org/10.1016/j. jprot.2016.02.029)

Dzyuba B, Bondarenko O, Fedorov P, Gazo I, Prokopchuk G \& Cosson J 2017 Energetics of fish spermatozoa: the proven and the possible. Aquaculture 472 60-72. (https://doi.org/10.1016/j.aquaculture.2016.05.038)

Dzyuba V \& Cosson J 2014 Motility of fish spermatozoa: from external signaling to flagella response. Reproductive Biology 14 165-175. (https://doi.org/10.1016/j.repbio.2013.12.005)

Dzyuba V, Cosson J, Dzyuba B \& Rodina M 2016 Oxidative stress and motility in tench Tinca tinca spermatozoa. Czech Journal of Animal Science 60 250-262. (https://doi.org/10.17221/8238-CJAS)

Fink B, Laude K, McCann L, Doughan A, Harrison DG \& Dikalov S 2004 Detection of intracellular superoxide formation in endothelial cells and intact tissues using dihydroethidium and an HPLC-based assay. American Journal of Physiology: Cell Physiology 287 C895-C902. (https://doi. org/10.1152/ajpcell.00028.2004)

Gazo I, Dietrich MA, Prulière G, Shaliutina-Kolešová A, Shaliutina $O$, Cosson J \& Chenevert J 2017 Protein phosphorylation in spermatozoa motility of Acipenser ruthenus and Cyprinus carpio. Reproduction 154 653-673. (https://doi.org/10.1530/REP-16-0662)

Huxley TS 1930 The maladaption of trout spermatozoa to fresh water. Nature 125 315-322.

Inaba K 2002 Dephosphorylation of Tctex2-related dynein light chain by type 2A protein phosphatase. Biochemical and Biophysical Research Communications 297 800-805. (https://doi.org/10.1016/S0006291X(02)02303-3)

Inaba K, Morisawa S \& Morisawa M 1998 Proteasomes regulate the motility of salmonid fish sperm through modulation of cAMP-dependent phosphorylation of an outer arm dynein light chain. Journal of Cell Science 111 1105-1115.

Itoh A, Inaba K, Ohtake H, Fujinoki M \& Morisawa M 2003 Characterization of a cAMPdependent protein kinase catalytic subunit from rainbow trout spermatozoa. Biochemical and Biophysical Research Communications 305 855-861. (https://doi.org/10.1016/S0006-291X(03)00840-4)

Kime DE, Van Look KJ, McAllister BG, Huyskens G, Rurangwa E \& Ollevier F 2001 Computer-assisted sperm analysis (CASA) as a tool for monitoring sperm quality in fish. Comparative Biochemistry and Physiology: Toxicology and Pharmacology 130 425-433. (https://doi. org/10.1016/S1532-0456(01)00270-8)

Kwon WS, Rahman MS, Lee JS, Kim J, Yoon SJ, Park YJ, You YA, Hwang S \& Pang MG 2014 A comprehensive proteomic approach to identifying capacitation related proteins in boar spermatozoa. BMC Genomics 15 897. (https://doi.org/10.1186/1471-2164-15-897)

Lahnsteiner F, Berger B \& Weismann T 1999 Sperm metabolism of the telost fishes Chalcalburnus chalcoides and Oncorhynchus mykiss and its relation to motility and viability. Journal of Experimental Zoology 284 454-465. (https://doi.org/10.1002/(SICI)1097-010X(19990901)284:4<454::AIDJEZ12>3.0.CO;2-O)

Lahnsteiner F, Mansour N, McNiven MA \& Richardson GF 2009 Fatty acids of rainbow trout (Oncorhynchus mykiss) semen: composition and effects on sperm functionality. Aquaculture 298 118-124. (https://doi. org/10.1016/j.aquaculture.2009.08.034)

Lahnsteiner F, Patzner RA \& Weismann T 1993 Energy resources of spermatozoa of the rainbow trout Oncorhynchus mykiss (Pisces, Teleostei). Reproduction, Nutrition, Development 33 349-360. (https:// doi.org/10.1051/rnd:19930404)

Laurindo FRM, Pescatore LA \& Fernandes Dde C 2012 Protein disulfide isomerase in redox cell signaling and homeostasis. Free Radical Biology and Medicine 52 1954-1969. (https://doi.org/10.1016/j. freeradbiomed.2012.02.037)

Lefièvre L, Chen Y, Conner SJ, Scott JL, Publicover SJ, Ford WCL \& Barratt CLR 2007 Human spermatozoa contain multiple targets for protein S-nitrosylation: an alternative mechanism of the modulation of sperm function by nitric oxide? Proteomics 7 3066-3084. (https://doi. org/10.1002/pmic.200700254) 
Lehti MS, Kotaja N \& Sironen A 2013 KIF3A is essential for sperm tail formation and manchette function. Molecular and Cellular Endocrinology 377 44-55. (https://doi.org/10.1016/j.mce.2013.06.030)

McCarthy MJ, Baumber J, Kass PH \& Meyers SA 2010 Osmotic stress induces oxidative cell damage to rhesus macaque spermatozoa. Biology of Reproduction 82 644-651. (https://doi.org/10.1095/ biolreprod.109.080507)

Morielli T \& O'Flaherty C 2015 Oxidative stress impairs function and increases redox protein modifications in human spermatozoa. Reproduction 149 113-123. (https://doi.org/10.1530/REP-14-0240)

Morisawa M 1985 Initiation mechanism of sperm motility at spawning in teleosts. Zoological Science 2 605-615.

Morisawa M \& Suzuki K 1980 Osmolality and potassium ion: their roles in initiation of sperm motility in teleosts. Science 210 1145-1147. (https:// doi.org/10.1126/science.7444445)

Morisawa M, Suzuki K, Shimizu H, Morisawa S \& Yasuda K 1983 Effects of osmolality and potassium on motility of spermatozoa from freshwater cyprinid fishes. Journal of Experimental Biology 107 95-103.

Morisawa S \& Morisawa M 1988 Induction of potential for sperm motility by bicarbonate and $\mathrm{pH}$ in rainbow trout and chum salmon. Journal of Experimental Biology 136 13-22.

Nynca J, Arnold GJ, Fröhlich T \& Ciereszko A 2015 Cryopreservationinduced alterations in protein composition of rainbow trout semen. Proteomics 15 2643-2654. (https://doi.org/10.1002/ pmic.201400525)

Nynca J, Dietrich GJ, Dobosz S, Grudniewska J \& Ciereszko A 2014 Efficient method for cryopreservation of brown trout semen. Aquaculture 433 62-65. (https://doi.org/10.1016/j.aquaculture.2014.05.037)

Nynca J, Dietrich GJ, Liszewska E, Judycka S, Karol H, Dobosz S, Kromb J \& Ciereszko A 2016 Usefulness of a portable flow cytometer for sperm concentration and viability measurements of rainbow trout spermatozoa. Aquaculture 451 353-356. (https://doi.org/10.1016/j. aquaculture.2015.09.027)

Peixoto ÁS, Geyer RR, Iqbal A, Truzzi DR, Moretti AIS, Laurindo FRM \& Augusto O 2018 Peroxynitrite preferentially oxidizes the dithiol redox motifs of protein disulfide isomerase. Journal of Biological Chemistry 293 1450-1465. (https://doi.org/10.1074/jbc.M117.807016)
Pereira R, Sá R, Barros A \& Sousa M 2017 Major regulatory mechanisms involved in sperm motility. Asian Journal of Andrology 19 5-14. (https:// doi.org/10.4103/1008-682X.167716)

Roy A, Lin YN, Agno JE, DeMayo FJ \& Matzuk MM 2009 Tektin 3 is required for progressive sperm motility in mice. Molecular Reproduction and Development 76 453-459. (https://doi.org/10.1002/mrd.20957)

Schorr-Lenz AM, Alves J, Henckes NAC, Seibel PM, Benham AM \& Bustamante-Filho IC $2016 \mathrm{GnRH}$ immunization alters the expression and distribution of protein disulfide isomerases in the epididymis. Andrology 4 957-963. (https://doi.org/10.1111/andr.12205)

Si Y \& Okuno M 1993 The sliding of the fibrous sheath through the axoneme proximally together with microtubule extrusion. Experimental Cell Research 208 170-174. (https://doi.org/10.1006/excr.1993.1235)

Stoss J 1983 Fish gamete preservation and spermatozoa physiology. Fish Physiology 9 305-350.

Westfalewicz B, Dietrich MA \& Ciereszko A 2015 Impact of cryopreservation on bull (Bos taurus) semen proteome. Journal of Animal Science 93 5240-5253. (https://doi.org/10.2527/jas.2015-9237)

Wilson-Leedy JG \& Ingermann RL 2011 Production of nitric oxide by sperm of the steelhead (Oncorhynchus mykiss) and its actions on motility and respiration. Theriogenology 75 144-154. (https://doi.org/10.1016/j. theriogenology.2010.07.020)

Yoshioka J 2015 Thioredoxin superfamily and its effects on cardiac physiology and pathology. Comprehensive Physiology 5 513-530. (https://doi.org/10.1002/cphy.c140042)

Zilli L, Schiavone R, Storelli C \& Vilella S 2008 Molecular mechanisms determining sperm motility initiation in two sparids (Sparus aurata and Lithognathus mormyrus). Biology of Reproduction 79 356-366. (https:// doi.org/10.1095/biolreprod.108.068296)

Received 9 January 2019

First decision 31 January 2019

Revised manuscript received 25 February 2019

Accepted 1 March 2019 